\title{
Mental Health in Adolescents
}

\author{
Lubhana Malik Mental* \\ Department of Psychology, University of Delhi, India
}

Submission: Febuary 25, 2019; Published: March 05, 2019

*Corresponding author: Lubhana Malik Mental, Department of Psychology, University of Delhi, India

Keywords: Intervention; Disturbances; Vocationally; Adolescents; Anxious

\section{Opinion}

Adolescents, at the cusp of adulthood, go through a lot of changes, not just hormonal but emotional and psychological, as well. These include various difficulties and burdens that interfere with adolescent development and may adversely affect their quality of life intervention socially, and vocationally. Mental health problems have important implications for every aspect of a young person's life including his/her ability to engage with education, make and keep friends, have constructive family relationships and/or make his/her own way in the world. Thus, prevention and intervention in adolescence is critical for wellbeing, especially to be able to have a healthy transition into adulthood.

Mental health disturbances in adolescence, although a significant problem, are relatively common but amenable to treatment and/or intervention. The impact of changing youth subcultures on behaviour and priorities can also make it difficult to define mental health and mental health problems in adolescents. However, the most common psychological problems faced by adolescents are low self-esteem, anxiety, depression, attention span, mood fluctuations and unhealthy relationships.

\section{Adolescents may need help if they:}

a. Often feel anxious or worried or panicked

b. Throw frequent tantrums or are intensely irritable most of the time

c. Experience frequent stomach-aches or headaches with no physical explanation

d. Have trouble sleeping, including frequent nightmares

e. Have trouble concentrating or focusing or sitting still for any length of time f. Have trouble doing well in school

g. Lose interest in things they used to enjoy, including spending time with friends

h. Fear gaining weight; and so exercise and/or diet obsessively

i. Have spells of either low energy or intense, inexhaustible activity

j. Harm themselves, in manners such as cutting or burning their skin

k. Engage in risky, destructive behaviour

l. Smoke, drink, or use drugs

m. Have suicidal thoughts

The identification, treatment, and follow-up of mental health problems in adolescents can be complicated. Parents and teachers may dismiss their problems as merely reflecting adolescent turmoil. Young people themselves are often very reluctant to seek help, owing to developmental needs about being considered "normal" at the time when they are exploring identity issues and trying to engage with peer groups. Many adults also feel that adolescents do not require help to handle stress and anxiety because they feel that, as an adolescent, they haven't actually seen as much in life to already be stressed. However, the stress or anxiety that an adolescent might feel in a given situation can be a multi-fold of that experienced by an adult because adolescents are already operating from an unsure terrain due to changes experienced in teenage years. And, if they get the right tools at this age, then they can develop good mental health habits, including enhanced social and problem-solving 
skills, coping ability, resilience, and good judgment that will help them tackle these issues for life!

This can be achieved through therapy. If an adolescent is struggling with poor self-image, stress, anxiety, sadness, academics or interpersonal relationships then therapy will be beneficial for them Therapy will help them improve how they view themselves, help develop their identity, understand and channelize their feelings of sadness, stress or anxiety and help them become the best versions of themselves.

It is, however, advisable to engage a therapist who has the competency to relate to young people, to detect mental health problems early, and to provide treatments that include individual therapy for the adolescent and family therapy, and, where appropriate, psychotropic medication.

\section{Your next submission with Juniper Publishers} will reach you the below assets

- Quality Editorial service

- Swift Peer Review

- Reprints availability

- E-prints Service

- Manuscript Podcast for convenient understanding

- Global attainment for your research

- Manuscript accessibility in different formats ( Pdf, E-pub, Full Text, Audio)

- Unceasing customer service

Track the below URL for one-step submission https://juniperpublishers.com/online-submission.php 